\title{
Introducing Critical Literacy to Pre-Service English Teachers through Fairy Tales
}

\author{
Introducir la literacidad crítica con estudiantes de Magisterio a través \\ de cuentos tradicionales
}

\section{Introduir la literacitat crítica amb estudiants de Magisteri a través dels contes tradicionals}

\author{
Nita Novianti. University of Tasmania. Universitas Pendidikan Indonesia, \\ nita.novianti@utas.edu.au; nitanoviantiwahyu@upi.edu \\ https://orcid.org/0000-0002-6136-4831
}

\begin{abstract}
The need for a more critical approach to English as a Foreign Language (EFL) teaching and learning is undeniable, yet little has been done to prepare teachers for teaching with this approach. This article reports one of the cycles on my action research study, involving a teacher educator and 35 pre-service English teachers. Together with the teacher educator, a unit on critical literacy was developed using fairy tales as the core text. In the unit, we introduced pre-service teachers to critical literacy through the critical reading, analysis, and rewriting of fairy tales for social transformation. They were assigned to rewrite a fairy tale as a form of social action and to reflect on the choices made in the rewriting process. The re-written fairy tales and the accompanying reflection essay were analysed using a rubric adapted from the four dimensions of critical literacy (Lewison et al., 2002). The re-written fairy tales and the reflections suggest the pre-service teachers' growing understanding of the non-neutrality of text, ability to read from a different perspective and offer an alternative one, and ability to identify socio-political issues, such as stereotypes, and to subvert them.
\end{abstract}

Keywords: critical literacy; EFL; fairy tales; pre-service English teachers

\section{Resumen}

La necesidad de un enfoque crítico de la enseñanza-aprendizaje del inglés como lengua extranjera es innegable, aunque se ha hecho bastante poco para preparar los y las docentes a enseñar des de este enfoque. Este artículo da cuenta de uno de los cicos de nuestro estudio de investigación-acción que involucra a una formadora de docentes y 35 estudiantes de Magisterio. Junto con la docente, se desarrolló una unidad sobre literacidad crítica a través de la lectura crítica, el análisis y la reescritura de cuentos tradicionales para la transformación social (Lewison et al., 2002). Los cuentos tradicionales reescritos y las reflexiones sugieren el aumento de la comprensión crítica de los y las docentes y la no neutralidad del texto, la habilidad de leer desde una perspectiva diferente y la habilidad de identificar problemas sociopolíticos como los estereotipos y subvertirlos.

Palabras clave: literacidad crítica; inglés como lengua extranjera; estudiantes de Magisterio de inglés. 


\section{Resum}

La necessitat d'un acostament crític a l'ensenyament-aprenentatge de l'anglés com a llengua estrangera és innegable, tot i que s'ha fet ben poc per preparar els i les docents per ensenyar des d'aquest acostament. Aquest article dona compte d'un dels cicles del nostre estudi d'investigació-acció que involucra una formadora d'ensenyants i 35 estudiants de Magisteri. Juntament amb la docent, es va desenvolupar una unitat sobre literacitat crítica a través de la lectura crítica, l'anàlisi i la reescriptura de contes tradicionals per a la transformació social (Lewison et al., 2002). Els contes tradicionals reescrits i les reflexions suggereixen l'augment de la comprensió crítica dels i les mestres i la no neutralitat del text, l'habilitat de llegir des d'una perspectiva diferent i l'habilitat d'identificar problemes sociopolítics com els estereotips i subvertir-los.

Paraules clau: literacitat crítica; anglés com a llengua estrangera; estudiants de Magisteri d'anglés

\section{Introduction}

Being literate in English in this twenty-first century is not sufficient to prepare English as a foreign language (EFL) students to be citizens who have the aspirations to participate in creating a democratic and just society. This need calls for the teaching of critical literacy that ultimately aims to promote social justice through literacy experiences (Lewison et al., 2002; Vasquez et al., 2019). Critical literacy that acknowledges the intricate relationships between power and English language learning (Dooley et al., 2016; Luke \& Dooley, 2011) has grown in popularity as an approach to teaching and learning in EFL classrooms in various countries. It has opened up spaces for discussions of real-world issues and encouragement of social transformation (Gómez Jiménez \& Gutierrez, 2019; Huh, 2016; Janks, 2012, 2014) in classes where formerly language competence was the sole focus. Preparing EFL teachers to be critical then becomes paramount, especially given its increasing perceived importance in the classrooms of English language teaching (ELT) in general and English as a foreign language (EFL) in particular (Dooley et al., 2016; Huh, 2016; Luke \& Dooley, 2011; Pennycook, 1990, 2001).

Critical literacy has also quite recently entered Indonesian EFL classrooms. It has been adopted as an instructional approach for teaching English at college (e.g. Setyaningsih, 2019; Suarcaya \& Prasasti, 2017) and secondary (e.g. Gustine, 2014; Gustine \& Insani, 2019; Kurniawati et al., 2020) levels. Despite its growing acceptance into the EFL classrooms, little attention has been given to preparing teachers to be critically literate and competent to teach from a critical perspective. Meanwhile, McLaughlin and DeVoogd (2020) argued, "The most challenging precondition for teaching critical literacy is that the teachers themselves must first become critically literate" (p. 588). Against this backdrop, the action research study sought to develop critical literacy skills with pre-service teachers that will hopefully be useful for teaching their future students with a critical approach. 
There are various strategies teacher educators have attempted to equip their pre-service teachers

Despite its growing acceptance into the EFL classrooms, little attention has been given to preparing teachers to be critically literate and competent to teach from a critical

following sections. with critical literacy skills. The pre-service English teachers in this particular action research were introduced to critical literacy through critical engagement with fairy tales. The reasoning behind the selection of fairy tales as the core text and further explanations of the contextual backgrounds and theoretical frameworks of the study are elaborated in the

\section{Critical Literacy for EFL Pre-Service Teachers}

The teaching and learning of English in the context where English is not the first language is strongly political (Dooley et al., 2016; Huh, 2016; Luke \& Dooley, 2011). Yet, in classrooms, English is often taught as a language whose main function is for communicative purposes (Huh, 2016), and teaching is focused more on grammar and vocabulary memorisation (Alwasilah, 2001, 2011; Gustine, 2014). Critical literacy then comes into the picture to highlight the political nature of English teaching and learning (Dooley et al., 2016; Huh, 2016). It encourages critical discussion and fosters critical awareness of learners in using and learning English as a foreign language (Gómez Jiménez \& Gutierrez, 2019; Huh, 2016).

Such critical discussion and consciousness-raising can only be facilitated by teachers who are critically literate. In this context, critically literate EFL teachers are those who are aware that the teaching of English is political-what they teach (and not teach) and how they teach are political actions that bear some consequences (Luke \& Dooley, 2011; Pennycook, 1990, 2001). EFL teachers who are critically literate also understand the relationship between language, in this case English, and power, and that English can be the key

In this action research, the focus is on raising pre-service teachers' awareness and understanding of the relationship between text and power by engaging them in critical reading and analysis of fairy tales. It is to access the dominant power (Luke \& Dooley, 2011). Finally, critically literate EFL teachers are also aware that students' socio-economic backgrounds affect how they learn English (Nikolov \& Mihaljević Djigunović, 2019; Pinter, 2017), so too their different cultural backgrounds which necessitate cultural awareness and sensitivity in teaching and learning (Pinter, 2017). In this action research, the focus is on raising pre-service teachers' awareness and understanding of the relationship between text and power by engaging them in critical reading and analysis of fairy tales. It is expected that this activity will help develop the pre-service teachers' critical stance which is necessary to help them become critically literate (Lewison et al., 2008; Pennycook, 1999). 


\section{Fairy Tales and Critical Literacy}

The term fairy tale traditionally refers to tales involving fairy characters (Ashliman, 2004; Zipes, 1979/1992), although it has been popularly used for tales of magic that have no fairy characters at all, such as Little Red Riding Hood and Hansel and Gretel. The term was derived from the French modern phrase, which was also the title of a book written by Countess D'Aulnoy (1697), Les Conte de Fees. The misnomer began when the term came to be translated into "Tales of the Fairys" in English (Ashliman, 2004; Zipes, 1979/1992) and later used to refer to the German folk tale (Volksmärchen) (Zipes, 1979/1992).

Originally part of the verbal folklore, the fairy tale, as argued by Zipes (1979/1992, 1983), was transformed into a print-based literary genre disseminated to the general public to serve the political purposes of some European countries' feudal and capitalist societies. The Brothers Grimm (Germany) and Charles Perrault (France) collected and reappropriated what would become today's most popular classic fairy tales. Although fairy tales were originally intended for adult readers, they were later targeted at child readers and as such have undergone much appropriation, as was done by the Brothers Grimm to the second edition of their collected fairy tales, Nursery and Household Tales published two years after its first edition in 1814 (Zipes, 1988). To this date, fairy tales have almost always been associated with children, especially after Disney adopted them into many children's films and animations consumed worldwide.

Traditionally, fairy tales serve as wish-fulfilment fantasy rooted in the European tradition of wonder tale (Lüthi, 1970; Zipes, 1979/1992). The tales give their readers some hope of restoration and justice, where the good will always be rewarded, and the bad will always be punished. Typically, fairy tales include characters from the extreme ends of the spectrum, the most beautiful and/or the ugliest, the king and/or the peasant, etc. (Lüthi, 1970). What primarily distinguishes fairy tales from other folktales such as legends is their non-specific ties to a particular place or culture; instead, they can be claimed for authorships and re-written for certain purposes (Zipes, 2015). Based on these characteristics, the fairy tale in this study is defined as a tale with fantasy elements, containing either fairies or non-fairy creatures, set in a magical and imaginary realm, and is part of the popular culture. The genre comprises the tales originating in oral traditions, such as those collected by the Brothers Grimm and Charles Perrault, and the modern tales created by specific authors, such as Marie-Catherine (Countess) D'Aulnoy and Hans Christian Anderson.

The use of fairy tales for teaching critical literacy is quite common in language classrooms across various contexts, from language arts to foreign language such as ELT. Fairy tales have been used to engage students in critical reading and analysis for encouraging social transformations at various levels 
and contexts, from early childhood and kindergarten (e.g. Kim, 2016; Kim \& Cho, 2017; Labadie et al., 2013; Maher, 2018; Wee et al., 2017) to primary school (e.g. Ajayi, 2012; Bourke, 2008; Karagiannaki \& Stamou, 2018), early secondary (e.g. Gustine \& Insani, 2019; Hayik, 2015, 2016), upper secondary (e.g. Ajayi, 2015), and to college level (e.g. Huang, 2019; Stasz \& Bennett, 1997).

Teachers and practitioners have cited the popularity and appeals of fairy tales to learners across ages and genders as one of the main reasons to use them as the core text in their critical literacy practice (Ajayi, 2012; Hayik, 2015, 2016; Karagiannaki \& Stamou, 2018; Stasz \& Bennett, 1997; Wee et al., 2017). This view is supported by scholars of fairy tales who highlight the universal popularity and appeal of fairy tales to people of all ages (Ashliman, 2004; Kole, 2018; Lüthi, 1970; Zipes, 1979/1992, 1983, 2013).

Fairy tales also carry certain messages or ideologies that speak for the interest of certain groups of people (Ashliman, 2004; Bobby, 2009; Zipes, 1979/1992, 1983). Because one of the primary concerns of critical literacy is to help learners uncover the ideologies, biases, and social injustices represented by text, many teachers have used fairy tales for this purpose with their students. Some of the popular topics addressed in critical literacy practices using fairy tales include gender (Garofalo, 2013; Hayik, 2015, 2016; Huang, 2019; Kim \& Cho, 2017; Tsai, 2010; Wee et al., 2017) and racial identity (Ajayi, 2012; Hsieh \& Matoush, 2012).

The final reason for using fairy tales for critical literacy practices is related to the ultimate goal of

Rewriting the fairy tale is then seen as an act of reconstructing the ideologies and countering them to promote social justice. critical literacy to encourage learners to participate in social action through reconstruction of text (Janks, 2000; Jones, 2006). Traditionally, fairy tales have been rewritten or revisited to fight against the hegemonic ideas represented or promoted by particular classic fairy tales (Tatar, 1999). Rewriting the fairy tale is then seen as an act of reconstructing the ideologies and countering them to promote social justice.

\section{Teaching Critical Literacy to Pre-Service Teachers Using Fairy Tales}

The potentials offered by fairy tales to teach critical literacy have also been recognised by teacher educators. Fairy tales have been used as the core text to teach critical literacy to pre-service teachers in the context of English language (e.g. Chou, 2007; Stasz \& Bennett, 1997). The most common activity to critically engage pre-service teachers is by inviting them to rewrite fairy tales to reconstruct gender and racial roles constructed in the tales. In some practices, the rewriting is done through 
transmediation, such as reported by Altenderfer et al. (2012), in which the pre-service teachers revisited Hansel and Gretel through parody in the form of a photography-based comic strip.

Although fairy tales have been quite popularly used in teaching critical literacy to EFL students (e.g. Gustine \& Insani, 2019; Hayik, 2015, 2016; Huang, 2019; Ko \& Wang, 2009), their use in teacher education has not been reported. In fact, not much research has reported how critical literacy is introduced to EFL pre-service teachers. Within the limited literature, Dominguez (2019) engaged rural Colombian pre-service teachers in critically analysing advertisements displayed in their surroundings. Gutiérrez (2015), together with three of her Colombian pre-service teachers, explored the pedagogical approaches using critical literacy. She provided them with articles showing how various teachers translate the approaches into classroom practices. Subsequently, they created lesson plans with critical literacy orientations. Finally, Ng (2017) reported how his pre-service teachers conducted microteaching by translating critical literacy into secondary English lessons. No such research has been reported in Indonesian contexts, leaving a gap to be filled in by the present study.

\section{Methods}

The aim of the present study is to introduce critical literacy to EFL pre-service teachers to help prepare them to teach with a critical stance in the future. To this end and considering the fact that this particular topic has not been widely researched, action research was the appropriate method to employ (Efron \& David, 2013; Savin-Baden \& Wimpenny, 2007). The present action research study sits within both the critical and pragmatic paradigms. From the critical point of view, it is motivated by an interest shared with the teacher educator "in liberating" (Mills, 2011, p. 6) learners from practices in English teaching and learning that ignore students' voices and identities and sustain cultural hegemony (Luke \& Dooley, 2011, p. 3). The action research also sits within the pragmatic paradigm (Mills, 2011) because it is part of my lifelong professional development, carried out in the university where I have been teaching, and the results are expected to help me improve my teaching and the practices of EFL teaching and learning in the university.

\subsection{Participants and Site}

I collaborated with a teacher educator and 35 pre-service teachers ( 31 female and 4 male students) taking the course of Practice of Teaching English to Young Learners. The pre-service teachers were enrolled in an English education study program in a busy city in Indonesia. Consent was obtained from the teacher educator and the pre-service teachers before the implementation of the critical literacy unit and after approval was received from the university ethics research committee. 


\subsection{The Unit}

I collaborated with the teacher educator to create a unit on critical literacy, embedded in the course taken by the pre-service teachers. The unit consisted of four sessions, in which the pre-service teachers were first introduced to story-based methodology, the fairy tale as an alternative genre for teaching English to young learners, and critical literacy as an alternative approach to teach English to young learners. The present article reports a part of the unit where the pre-service teachers were introduced to critical literacy and engaged in the critical reading and analysis of fairy tales for social transformation. The engagement was expected to help pre-service teachers gain better understanding of critical literacy and to have some ideas to teach critical literacy through fairy tales to their future students.

\subsection{Data Collection}

Data for this study were collected mainly from the pre-service teachers' group assignments on rewriting critical literacy along with their reflection essays. The primary data were triangulated with interviews conducted with some pre-service teachers, and my reflections and notes of critical moments during class sessions.

The fairy tale re-writing assignment required the pre-service teachers to select a fairy tale and re-write it by using the critical literacy skills guided by the Four Dimensions of Critical Literacy (Lewison, et. al, 2002). They were asked to first read the fairy tale critically, trying to identify the ideology represented in the tale, whose voice is present and whose is absent, and any hegemonic idea commonly taken for granted (disrupting the commonplace). Secondly, they were encouraged to read the tale from different and/or multiple perspectives; for example, by changing the perspective (point of view) and reversing the characterisations of the characters (protagonist to antagonist, evil to good, etc.) (interrogating multiple viewpoints). Thirdly, they were asked to identify any social injustices represented by the tale (focusing and sociopolitical issues) and to eventually think of any actions to take to address the injustices (taking social action).

The assignment was done in a group of three to four. The design of the assignment was selected to allow for critical discussions or dialogues, as one of the most important strategies in the teaching and learning of critical literacy (Freebody \& Luke, 1990; McLaughlin \& DeVoogd, 2004), to take place among the pre-service teachers. To ensure the contribution of each of the groups, the pre-service teachers were asked to write down their individual contributions to the assignment. 


\section{Data Analysis}

To find out the extent to which the pre-service teachers gained understandings of critical literacy, their assignment on rewriting a fairy tale and reflecting on the rewriting was analysed using the rubric adapted from Lewison's et al. (2002) four dimensions of critical literacy consisting of "disrupting the commonplace, interrogating multiple viewpoints, focusing on sociopolitical issues, and taking action and promoting social justice (p. 382). Lewison's et al. (2002) framework of critical literacy has been quite popularly used in teaching critical literacy in EFL classrooms (e.g. Gustine, 2014; Hayik, 2015, 2016). The framework has also been used as an analytical tool. Gustine (2014), for example, used this framework to analyse her students' responses to her critical literacy lesson on representations in advertisements. Hayik (2015) also used the framework to guide her analysis of her EFL secondary students' reconstruction of Cinderella, although she did not develop the framework into a rubric for the purpose.

In this study, I developed the framework into a rubric to analyse students' writing. The use of this framework as an analytical tool of student writing is what distinguishes my study from previous ones in which the fairy tale was used in teaching critical literacy to pre-service teachers. The previous studies (Chou, 2007; Stasz \& Bennett, 1997) did not use specific frameworks to analyse how the rewritten fairy tales show the writers' newly gained or developing understandings of critical literacy. The adapted rubric is presented in Table 1.

\begin{tabular}{|c|c|}
\hline Dimension & Indicators \\
\hline $\begin{array}{l}\text { Disrupting the } \\
\text { commonplace: "seeing the } \\
\text { everyday through new } \\
\text { lenses" (Lewison et al., 2002, } \\
\text { pp. 382-383) }\end{array}$ & $\begin{array}{l}\text { - Being able to identify the message that the fairy tale conveys, and } \\
\text { the general response expected from the reader. } \\
\text { - Being able to identify the ideology or hegemonic idea promoted } \\
\text { by the fairy tale that is usually taken for granted and question this } \\
\text { by looking at it from a new or fresh perspective. } \\
\text { - Being able to interrogate the fairy tale with such questions as: } \\
\text { How does the text position me as the reader? What } \\
\text { character/ideology is privileged in the text? Does the text contain } \\
\text { any biases against particular gender, race, class? Etc. }\end{array}$ \\
\hline $\begin{array}{l}\text { Interrogating multiple } \\
\text { viewpoints }\end{array}$ & $\begin{array}{l}\text { - Being aware of one's own perspective when reading the fairy } \\
\text { tale. } \\
\text { - Being able to re-write the fairy tale from a different perspective; } \\
\text { for example, using the point of view of one of the characters or } \\
\text { that of the marginalised/prejudiced character. }\end{array}$ \\
\hline
\end{tabular}




\begin{tabular}{lll}
\hline $\begin{array}{l}\text { Focusing on sociopolitical } \\
\text { issues }\end{array}$ & $\begin{array}{l}\text { Being able to identify social injustices (stereotypes, biases, } \\
\text { prejudices against certain gender, race, or culture, etc.) in the } \\
\text { fairy tale. }\end{array}$ \\
\hline $\begin{array}{l}\text { Taking action and promoting } \\
\text { social justice. }\end{array}$ & $\begin{array}{l}\text { Being able to subvert the identified social injustices by changing } \\
\text { the characterisation of the character(s). }\end{array}$ \\
& $\begin{array}{l}\text { Radically changing the storyline of the fairy tale to promote social } \\
\text { justice. }\end{array}$
\end{tabular}

Table 1. Rubric for Assessing Students' Re-Written Fairy Tale and Reflection Essay

The four dimensions are interrelated and at times overlapping, in which a particular excerpt in the re-written fairy tale or reflective essay may reflect one or more dimensions. For example, two dimensions of critical literacy can be found in the following excerpt by the group of preservice teachers rewriting The Little Mermaid, "She was too young when she married Prince Eric[;] she was 16 at the time

Another dimension is focusing on a sociopolitical issue, in which the preservice teachers readily identify the social issue of underage marriage and focus on this issue throughout the rewritten fairy tale and the reflection. in the original story." The first dimension is the ability to disrupt the commonplace, to be aware that the fairy tale promotes underage marriage, which is a common case for many fairy tales. This fresh perspective disrupts the commonplace in that many usually overlook underage marriage and romanticise it. Another dimension is focusing on a sociopolitical issue, in which the pre-service teachers readily identify the social issue of underage marriage and focus on this issue throughout the rewritten fairy tale and the reflection.

A total of 12 assignments were submitted by the pre-service teachers. Out of the 12 assignments, two were not included in the analysis because they did not follow the prompt carefully. The first group (group 2) selected Frankenstein by Mary Wollstonecraft, which belongs to the science fiction genre, and the second group chose The Two Goats, which was part of Aesop Fables. The Ugly Duckling and Alamat $\mathrm{Ng}$ Sibuyas can be both categorized as fable and legend, respectively. However, based on the criteria of fairy tales as described in the previous section, the two are considered fairy tales because, among others, they have been rewritten for certain purposes with claimed authorships. They are also not attached to a particular place or setting. Alamat $\mathrm{Ng}$ Sibuyas, for instance, originally derives from Filipino folktales. However, it has been re-written and reappropriated into various settings. The same can be said about The Magic Pot that is said to have originated from Chinese folktales.

Another way of ensuring whether the pre-service teachers were aware of the categorization was by asking them why they chose the respective tales. Upon being questioned for their selection, Group 2 
and group 7 admitted they were not really sure of the fairy tale genre and had a misconception that fantasy and fables were included under the genre. On the other hand, group 9 argued that Alamat $\mathrm{Ng}$ Sibuyas belonged to the category of fairy tale because the version they adopted was popularised by a specific author who made many changes to the original tale for entertainment purposes.

\section{Findings and Discussion}

The findings show that most of the fairy tales selected by the pre-service teachers for the assignment were the classic tales popularised by Disney, including The Little Mermaid, The Ugly Duckling (three groups), Rapunzel, Little Red Riding Hood, Cinderella, and Aladdin. These fairy tales also share the similarity of originating from European countries, except for Aladdin which is believed to be part of the Middle Eastern tale 1001 Arabian Nights. Only two groups chose a fairy tale that originated and circulated in Asia, namely Alamat Ng Sibuyas/The Legend of Onion (the Philippines) and The Magic Pot.

The selection can be explained by the popularity of Disney fairy tales among children and adults alike.

[...]the analysis of the 10 rewritten fairy tales and the accompanying reflective essays indicate that to a great extent the pre-service teachers have gained the abilities to read the fairy tales from a fresh perspective, present a different viewpoint to the story, identify social injustice and other sociopolitical issues in the tale, and rewrite the fairy tale to address the social injustices represented by the tale
The Australian pre-service teachers (adults) in Chou's study (2007) and the American primary school children in Ajayi's study (2012), for example, listed fairy tales popularised by Disney, such as Snow White, Cinderella, Hansel and Gretel, etc. when asked to share their favourite fairy tales. A similar phenomenon was reported in non-English speaking countries, such as Korea (Kim \& Cho, 2017; Wee et al., 2017) and Greece (Karagiannaki \& Stamou, 2018). In this regard, it seems that the Indonesian EFL pre-service teachers have also been familiar with the Disneyfied fairy tales.

With regard to how the assignments reflect the pre-service teachers' understandings of critical literacy, the analysis of the 10 re-written fairy tales and the accompanying reflective essays indicate that to a great extent the pre-service teachers have gained the abilities to read the fairy tales from a fresh perspective, present a different viewpoint to the story, identify social injustice and other sociopolitical issues in the tale, and rewrite the fairy tale to address the social injustices represented by the tale, reflecting the four dimensions of critical literacy identified by Lewison et al. (2002). 


\subsection{Disrupting the commonplace}

All groups of pre-service teachers were able to read the fairy tales from a fresh perspective or question the ideas commonly taken for granted in them. In general, they could see some ideas related to gender roles, discrimination or bullying, and stereotypes of certain characters that have been perpetuated by fairy tales and subsequently taken for granted by general readers. Gender roles are the most predominant ideas disrupted by the pre-service teachers, as found in groups rewriting the tales of The Little Mermaid, Cinderella, Rapunzel, and Alamat Ng Sibuyas. This finding resonates with Zipes' (2013) argument that fairy tales have been created and disseminated, among others, to sustain the dominant patriarchal ideology that survived through the 19th and 20th centuries. Patriarchal ideology places women as the second gender, and fairy tales generally represent women this way.

In addition to gender roles, the pre-service teachers in group 1 were able to see the concept of marriage at a young age promoted by The Little Mermaid. In their reflection, they reasoned: "She was too young when she married Prince Eric; she was 16 at the time in the original story." This concept is generally overlooked and at times romanticised in fairy tales. Many fairy tale female characters marry at a young age, such as those in Beauty and the Beast, Cinderella, and Snow White. Marriage is also frequently promoted as the ultimate goal of women's lives in fairy tales (Lieberman, 1972; Neikirk, 2009). The pre-service teachers saw marriage at a young age from a fresh perspective. They disrupted the romanticisation of marriage for young women.

The rest of the groups were able to identify the stereotypical characters commonly represented in fairy tales, such as the bad wolf (Little Red Riding Hood), the orphan thief (Aladdin), the greedy/foolish king (The Magic Pot), and the beauty versus the ugly/beast (The Ugly Duckling). Group 8 (Aladdin), for instance, noticed the original story promotes stealing as a means of survival for poor orphans, as shown in their reflection: "poor, abandoned orphan children ... will always have bad behavior and do crimes in order to survive." The idea of orphans as petty criminals who survive by stealing and doing other petty crimes is promoted and sustained in fairy tales and other forms of literature (Wagner, 2012). The pre-service teachers were able to see this stereotype from a fresh perspective, arguing that being orphans should not be associated with criminals.

\subsection{Interrogating multiple viewpoints}

The next dimension, "interrogating multiple viewpoints," is concerned with the ability to read the story and rewrite it from different or multiple perspectives. In general, the strategies employed by the pre-service teachers to present the story from a different perspective include switching or changing the characters and/or characterisations and presenting the perspective of a different character whose voice or perspective is commonly unheard in the original fairy tales. 
The groups that switched and/or changed the characters' characterisations include The Little Mermaid, The Ugly Duckling (group 5), Alamat Ng Sibuyas, and The Magic Pot. The group rewriting The Little Mermaid switched the traits and behaviors of the prince with those of Ariel. Instead of Ariel falling deeply and blindly in love with the prince, it is the prince who falls in love with her. An excerpt of the tale demonstrates this switch: "And he thought he fell in love[;] he fell for Ariel. He tried to find a way to go to Ariel's house." In the original story, it is Ariel who struggles to go to the land of the prince, even going as far as sacrificing her voice in exchange for feet. Similarly, in the re-written The Ugly Duckling, the group decided to switch the mother duck character with a swan to remove the original "switched at birth" motive and highlight the idea of maturation. In Alamat Ng Sibuyas, the pre-service teachers switched the gender of the main character, Sibuyas, from a girl to a boy, to send a message that boys can also cry. Finally, group 4 rewriting The Magic Pot chose to change the king, from a greedy one to a wise one, to avoid a bad ending to the story as in the original version where the king died because of his greed.

The rest of the groups chose to center the perspectives of other characters: the wolf (Little Red Riding Hood), the witch (Rapunzel), the villagers (Cinderella), Jasmine's father, the king (Aladdin), or animals on the farm (The Ugly Duckling-group 6). The Little Red Riding Hood group chose to include the perspective of the wolf in the tale to emphasise their concern with deforestation and the loss of natural habitats for animals caused by human greed. The Rapunzel group decided to tell the story of the witch so that readers could better understand her motives and intentions toward Rapunzel. Similarly, the character of the king in Aladdin was given a voice and changed his disposition from one who sees the value of people based on their wealth to one who values personality and attitudes more. Finally, the supporting animals in The Ugly Duckling (group 6) were given a voice in the story to promote the idea of respecting and accepting the ugly

duckling as a different duck, instead of ugly.

The strategies employed by the pre-service teachers are referred to as "character substitution" and "character perspective," respectively by McLaughlin and DeVoogd (2004). McLaughlin and DeVoogd (2004) explained
By interrogating their own perspectives and exploring the perspectives of other characters who are silent or not given enough voice, the pre-service teachers were able to gain an awareness that a story may give voice to further how these strategies are effective to help students examine alternative perspectives and explore "the viewpoints of different characters in a story or different people in a real-life situation" (p. 49). By interrogating their own perspectives and exploring the perspectives of other characters who are silent or not given enough voice, the pre-service teachers were able to gain an awareness that a story may give voice to certain characters and hence socio-cultural groups but not to other groups. 


\subsection{Focusing on socio-political issues}

For the third dimension, all groups, except group 4 (The Magic Pot), were able to identify the sociopolitical issues raised in the fairy tales. As shown by Table 2 , the issues identified were mostly concerned with stereotypes related to gender and race, although other issues, such as bullying, marriage at a young age, deforestation, and stereotypes of certain cultural groups, were also observed. As Chou (2007) contended, "Critiquing through recreation of fairy tales can reveal biases of personal and cultural constructions of race and gender" (p. 55). The majority of the pre-service teachers in Chou's study (2007) were also found to be focused on gender in their reconstruction of the fairy tales. All groups, except one, were reported to have selected fairy tales with a female main character.

In other classrooms, fairy tales have also been reported to be used as the core text in critical literacy practices that dealt with gender representation, particularly women. Garofalo (2013) invited Canadian primary school students to analyse how Disney's powerful female characters are usually portrayed as being evil and ugly. Hayik $(2015,2016)$ engaged her early secondary Arab-Israeli students in reconstructing Cinderella to transform gender bias represented in the fairy tale. Other teachers also reported similar focus on gender representation in fairy tales with their respective students in various contexts (Huang, 2019; Kim \& Cho, 2017; Tsai, 2010; Wee et al., 2017).

\begin{tabular}{cll}
\hline Group & Tale & Social justice issues identified \\
\hline 1 & The Little Mermaid & Underage marriage and the stereotype of women \\
& & $\begin{array}{l}\text { blindly falling in love with man, sacrificing everything } \\
\text { for them }\end{array}$ \\
\hline 3 & The Ugly Duckling & Bullying \\
\hline 5 & The Ugly Duckling & The stereotypical idea of beauty and the \\
& & marginalization of those that do not meet the \\
& & standards of beauty, bullying \\
\hline 6 & The Ugly Duckling & The stereotype of black is ugly and white is beautiful; \\
& & bullying \\
\hline 8 & Aladdin & The stereotype of orphans as petty criminals \\
\hline 10 & Rapunzel & The gender stereotype of masculinity versus \\
& & femininity in dealing with emotions
\end{tabular}




\begin{tabular}{lll} 
& Little Red Riding Hood & $\begin{array}{l}\text { The stereotypical idea of animal as bad and human as } \\
\text { good; deforestation }\end{array}$ \\
\hline 12 & Cinderella & The promotion of competition instead of support \\
& & among women
\end{tabular}

Table 2. List of socio-political issues identified in the tales

Interestingly, the pre-service teachers in this study unearthed more socio-political issues than gender and race. Bullying, for instance, was the issue identified by all groups rewriting The Ugly Duckling, which has been attested to by other researchers as well (e.g. Slee, 2017; Utami, 2018). There is also the issue of deforestation brought forward by the group rewriting Little Red Riding Hood that is believed to have been caused by human greed, as represented by the wood cutter.

At some point, this dimension may seem to be overlapping with the dimension of "disrupting the commonplace." However, the dimension of "focusing on sociopolitical issues" is more than being able to identify stereotypes or commonly taken for granted ideas in the fairy tale. This dimension takes this identification of social justice issues further by relating them to the real-world situation. Group 5 (The Ugly Duckling), for example, was aware that the standards of beauty have marginalised certain societies, especially those who are from the marginalized groups: "Societies have marginalized those who are different ... People from other races with darker tones are seen as different . . body [shaming] is everywhere" (reflection essay).

\subsection{Taking action and promoting social justice}

Essentially, the act of rewriting or reconstructing a fairy tale is considered a social action. As Lewison et al. (2008) contended, encouraging students to be agents of change can be strengthened "when students compose their own narratives, counternarratives, letters, essays, reports, poems, commercials, posters, plays, and webpages to promote social change" (p. 21). Based on the analysis, it was found that most of the groups incorporated this dimension of taking action and promoting social justice in their rewritten fairy tales. The majority of the pre-service teacher groups changed the storyline of the fairy tales and/or transformed some of their characters to realise this goal.

As an example, the Cinderella group radically changed the story by removing the part of the sisters competing to go to the ball and get noticed by the prince. Instead, the group decided to solely focus on the education of Cinderella and how the stepmother and stepsisters all helped her to be successful in her education. The group also transformed the stepmother's and stepsisters' characterisations from evil to good and were very supportive of Cinderella's education pursuits.

Group 3 (The Ugly Duckling) and group 4 (The Magic Pot) were found to have not included this dimension in their fairy tales. In The Ugly Duckling, the pre-service teachers failed to elaborate upon 
the new idea of maturation and how it relates to bullying. In the reflection, they said they would like to raise the issue of bullying that happens in the close environment of the bullied. However, in the story the bullying stopped only because the ugly duckling transformed into a beautiful swan, not because the bullies learned a lesson or realised they made any mistake. In The Magic Pot, although the story's ending changes into a happy one due to the new characterisation of the king as a wise man, the reflection did not show the reasoning for the change and what social issue was uncovered and addressed. Their main concern was in simplifying the story to suit young readers. They also explained their attempts at localising the story by changing the setting to rice fields but failed to explain why such localisation is necessary.

\section{Conclusions}

Introducing critical literacy to pre-service teachers or undergraduate students in general is not an easy task, as is noted by Bartlett (2009) and Lee (2016). It is even more challenging with EFL pre-service teachers who have never had experience with teaching English from a critical stance and who have always seen the teaching of English as a neutral activity to help learners be fluent in a language used internationally. Within the limited literature on this particular topic of critical literacy and pre-service teachers, the present action research has attempted to engage EFL pre-service teachers in disrupting the fairy tale, interrogating it from multiple perspectives, identifying socio-political issues in the tale, and reconstructing the work as a form of social action (Lewison et al., 2002).

Critical literacy was a relatively new concept for the pre-service teachers; however, when introduced through critical engagement with fairy tales, they seemed to not only enjoy the activity but also gain understandings of some of the key tenets of critical literacy, particularly concerning the interplay between text and power. Through the engagement, the pre-service teachers became aware that fairy tales, which are frequently perceived as 'innocent' children's tales, are not that innocent. When critically analysed, the tales were found to promote certain ideologies, stereotypes and marginalisation of certain groups of people. This awareness of the political nature of text is important because "awareness is an initial step in the process of change" (Pennycook, 1999, p. 336). Through this activity of critically engaging with fairy tales by questioning the tales for their biases and assumptions, the pre-service teachers are expected to apply the same questioning attitude to whatever text they will encounter in their future teaching and learning.

In the feedback to the unit more than half of the pre-service teachers mentioned this particular activity helped improve their understanding of some of the key concepts of critical literacy. This positive feedback is most possibly attributed to the use of the fairy tale for the critical engagement. The preservice teachers were already familiar with fairy tales, especially those popularised by Disney. As 
argued by Lee (2016), “children's books present difficult issues in a way that is comprehensible to adults as well as children while the significance of the issues presented in the books is not compromised" (p. 50). Engaging with the tales was consequently fun and enlightening.

The most important challenge observed was the ability to reflect, which is important for teachers to be critically literate. While all the fairy tales were reconstructed in ways that suggest some attempts at social transformations, these attempts were not wellelaborated in the reflections by some groups.
However, certainly there were also challenges encountered throughout the critical engagement with fairy tales. The most important challenge observed was the ability to reflect, which is important for teachers to be critically literate (Lewison et al., 2008). While all the fairy tales were reconstructed in ways that suggest some attempts at social transformations, these attempts were not well-elaborated in the reflections by some groups. The Magic Pot group, for example, transformed the story from having a bad ending to a good one by changing the greedy king into a wise king.

However, the reflection essay did not explain why the transformation was done and what social injustice was identified from the original story that necessitated such transformation.

Certainly, more efforts should be made to help EFL pre-service teachers become critically literate and better able to learn how to teach with a critical edge in the future. The present action research hopefully can serve as an impetus for EFL teacher education to consider teaching critical literacy to pre-service teachers.

\section{References}

Ajayi, L. (2012). Video "reading" and multimodality: A study of ESL/literacy pupils' interpretation of "Cinderella" from their socio-historical perspective. Urban Review: Issues and Ideas in Public Education, 44(1), 60-89.

Ajayi, L. (2015). Critical multimodal literacy: How Nigerian female students critique texts and reconstruct unequal social structures. Journal of Literacy Research, 47(2), 216-244.

Altenderfer, E., Doerfler, A., Poblete, E., Williamson, M., \& Yenika-Agbaw, V. (2012). Traditional tales and literacy: Pre-service teachers' transmediation of "Hansel and Gretel". Journal of Language and Literacy Education, 8(1), 38-48.

Alwasilah, C. A. (2001). Language, culture and education. Andira.

Alwasilah, C. A. (2011). Integrating local wisdom into language teaching CONAPLIN. Bandung.

Ashliman, D. L. (2004). Folk and fairy tales: A handbook. Greenwood Press.

Bartlett, A. (2009). Preparing pre-service teachers to teach for social justice and social change. The International Journal of Learning, 15(12), 37-43.

Bobby, S. R. (2009). Fairy tales reimagined: Essays on new retellings. McFarland \& Company, Inc.

Bourke, R. T. (2008). First graders and fairy tales: One teacher's action research of critical literacy. Reading Teacher, 62(4), 304-312. https://doi.org/10.1598/Rt.62.4.3 
Chou, W.-H. (2007). Contamination of childhood fairy tale: Pre-service teachers explore gender and race constructions. Journal of Social Theory in Art Education, 27, 55-73.

Dominguez, C. (2019). Critical awareness of media and teacher education: An experience with Colombian ELT pre-service teachers. Journal of Media Literacy Education, 11(1), 32-51. https://doi.org/10.23860/jmle2019-11-1-2

Dooley, K., Exley, B., \& Poulus, D. (2016). Research on critical EFL literacies: An illustrative analysis of some college level programs in Taiwan. English Teaching \& Learning, 40(4), 39-64.

Efron, S. E., \& David, R. (2013). Action research in education: A practical guide. The Guilford Press.

Fajardo, M. F. (2015). A review of critical literacy beliefs and practices of English language learners and teachers. University of Sydney Papers in TESOL, 10, 29-56.

Freebody, P., \& Luke, A. (1990). Literacies programs: Debates and demands in cultural context. Prospect: An Australian Journal of TESOL, 5(3), 7-16.

Garofalo, M. (2013). The Good, the Bad, and the Ugly: Teaching critical media literacy with Disney. Procedia Social and Behavioral Sciences, 106, 2822-2831. https://doi.org/10.1016/j.sbspro.2013.12.325

Gómez Jiménez, M. C., \& Gutierrez, C. P. (2019). Engaging English as a Foreign Language students in critical literacy practices: The case of a teacher at a private university. Profile: Issues in Teachers' Professional Development, 21(1), 91-105. https://doi.org/10.15446/profile.v21n1.71378

Gustine, G. G. (2014). Critical literacy in an Indonesian EFL setting: Sustaining professional learning Deakin University]. Australia.

Gustine, G. G., \& Insani, H. N. (2019). English students' experience of reframing narrative stories from a critical literacy perspective. Indonesian Journal of Applied Linguistics, 8(3), 691-696. https://doi.org/10.17509/ijal.v8i3.15254

Gutiérrez, C. (2015). Beliefs, attitudes, and reflections of EFL pre-service teachers while exploring critical literacy theories to prepare and implement critical lessons. Colombian Applied Linguistics Journal, 17(2), 179-192. https://doi.org/10.14483/udistrital.jour.calj.2015.2.a01

Hayik, R. (2015a). Addressing religious diversity through children's literature: An "English as a Foreign Language" classroom in Israel. International Journal of Multicultural Education, 17(2), 92-106. https://doi.org/10.18251/ijme.v17i2.911

Hayik, R. (2015b). Diverging from traditional paths: Reconstructing fairy tales in the EFL classroom. Diaspora, Indigenous, and Minority Education, 9(4), 221-236. https://doi.org/10.1080/15595692.2015.1044084

Hayik, R. (2016). What does this story say about females? Challenging gender-biased texts in the Englishlanguage classroom. Journal of Adolescent \& Adult Literacy, 59(4), 409-419. https://doi.org/10.1002/jaal.468

Hayik, R. (2018). Through their eyes: Israeli-Arab students speak up through participatory documentary photography projects. Language Teaching Research, 22(4), 458-477. https://doi.org/10.1177/1362168816683558

Hsieh, I. H., \& Matoush, M. M. (2012). Filial daughter, woman warrior, or identity-seeking fairytale princess: Fostering critical awareness through Mulan. Children's Literature in Education, 43(3), 213-222. https://doi.org/10.1007/s10583-011-9147-y

Huang, S. Y. (2019). Postfeminist influences on fairy tales, real and imagined: A critical media literacy classroom investigation [Periodical]. Gender and Education, 31(6), 688-704. https://doi.org/10.1080/09540253.2018.1467002

Huh, S. (2016). Instructional model of critical literacy in an EFL context: Balancing conventional and critical literacy. Critical Inquiry in Language Studies, 13(3), 210-235.

https://doi.org/10.1080/15427587.2016.1154445 
Janks, H. (2000). Domination, access, diversity and design: A synthesis for critical literacy education.

Educational Review, 52(2), 175-186. https://doi.org/10.1080/713664035

Janks, H. (2012). The importance of critical literacy. English Teaching: Practice and Critique, 11(1), 150-163.

Janks, H. (2014). Critical literacy's ongoing importance for education. Journal of Adolescent \& Adult Literacy, 57(5), 349-356. https://doi.org/10.1002/jaal.260

Jones, S. (2006). Girls, social class and literacy: What teachers can do to make a difference. Heinemann.

Karagiannaki, E., \& Stamou, A. G. (2018). Bringing critical discourse analysis into the classroom: A critical language awareness project on fairy tales for young school children. Language Awareness, 27(3), $222-242$. https://doi.org/10.1080/09658416.2018.1444046

Kim, S. J. (2016). Opening up spaces for early critical literacy: Korean kindergarteners exploring diversity through multicultural picture books. Australian Journal of Language \& Literacy, 39(2), 176-187.

Kim, S. J., \& Cho, H. (2017). Reading outside the box: Exploring critical literacy with Korean preschool children. Language and Education, 31(2), 110-129. https://doi.org/10.1080/09500782.2016.1263314

Ko, M. Y., \& Wang, T. F. (2009). Introducing critical literacy to EFL teaching: Three Taiwanese college teachers' conceptualization. Asian EFL Journal, 11(1), 174-191.

Ko, M. Y., \& Wang, T. F. (2013). EFL learners' critical literacy practices: A case study of four college students in Taiwan. Asia-Pacific Education Researcher, 22(3), 221-229. https://doi.org/10.1007/s40299-012-0013-5

Kole, K. (2018). The role of fairy tales in affective learning: Enhancing adult literacy and learning in FE and community settings. Australian Journal of Adult Learning, 58(3), 365-389.

Kurniawati, N., Sugaryamah, D., \& Hasanah, A. (2020). Proposing a model of critical literacy program for fostering Indonesian EFL students' critical thinking skills. Journal of Education and Learning, 14(2), $234-247$.

Labadie, M., Pole, K., \& Rogers, R. (2013). How kindergarten students connect and critically respond to themes of social class in children's literature. Literacy Research and Instruction, 52(4), 312-338. https://doi.org/10.1080/19388071.2013.809176

Larson, K. R. (2014). Critical pedagogy(ies) for ELT in Indonesia. TEFLIN, 25(1), 122-139.

Lau, M. C. (2010). Practising critical literacy work with English language learners: An integrative approach [Doctoral dissertation, University of Toronto]. TSpace Repository. https://hdl.handle.net/1807/24804

Lee, C.-J. (2016). Teaching multiple literacies and critical literacy to pre-service teachers through children'sliterature-based engagements. Journal of Language \& Literacy Education, 12(1), 40-52.

Lewison, M., Flint, A. S., \& van Sluys, K. (2002). Taking on critical literacy: The journey of newcomers and novices. Language Arts, 79(5), 382-392.

Lewison, M., Leland, C., \& Harste, J. C. (2008). Creating critical classrooms: $K-8$ reading and writing with an edge. Taylor and Francis Group. https://doi.org/10.4324/9780203826317

Lieberman, M. R. (1972). "Some day my prince will come": Female acculturation through the fairy tale. College English, 34(3), 383-395.

Luke, A., \& Dooley, K. (2011). Critical literacy and second language learning. In E. Hinkel (Ed.), Handbook of research in second language teaching and learning (pp. 856-868). Routledge.

Lüthi, M. (1970). Once upon a time: On the nature of fairy tales (L. Chadeayne \& P. Gottwald, Trans.). Frederick Ungar Publishing Co.

Maher, K. M. (2018). Exploring kindergartners' understandings of gender: Responding to picture book read alouds with a focus on fairy tales [Publication No. ED591488] [Doctoral Dissertation, State University of New York at Albany]. ProQuest Dissertations \& Theses Global.

McLaughlin, M., \& DeVoogd, G. (2004). Critical literacy: Enhancing students' comprehension of text. Scholastic. 
McLaughlin, M., \& DeVoogd, G. (2020). Critical expressionism: Expanding reader response in critical literacy. Reading Teacher, 73(5), 587-595. https://doi.org/10.1002/trtr.1878

Mills, G. E. (2011). Action research: A guide for the teacher researcher. (4th ed.). Pearson Education Inc.

Neikirk, A. (2009). “... Happily Every After” (or what fairytales teach girls about being women). Hohonu, 7, 3842.

$\mathrm{Ng}, \mathrm{C} . \mathrm{H}$. (2017). Pre-service teachers teaching critical literacy through microteaching: Possibilities and constraints. Changing English, 24(1), 81-90. https://doi.org/10.1080/1358684x.2016.1273759

Nikolov, M., \& Mihaljević Djigunović, J. (2019). Teaching young language learners. In X. Gao (Ed.), Second handbook of English language teaching (pp. 577-599). Springer Nature Switzerland AG.

https://doi.org/https://doi.org/10.1007/978-3-030-02899-2_31

Papadopoulos, I., \& Griva, E. (2017). Promoting critical literacy in the EFL context: Implementing a project to young learners. European Journal of Language and Literature Studies, 3(1), 107-120.

Pennycook, A. (1990). Critical pedagogy and second language education. System, 18(3), 303-311. https://doi.org/10.1016/0346-251X(90)90003-N

Pennycook, A. (1999). Introduction: Critical approaches to TESOL. TESOL Quarterly, 33(3), 329-348.

Pennycook, A. (2001). Critical applied linguistics: A critical introduction. Lawrence Erlbaum.

Pinter, A. (2017). Teaching young language learners (2nd ed.). Oxford University Press.

Rahimi, A., \& Askari Bigdeli, R. (2015). Why does critical literacy hit a snag in the Iranian EFL setting?. Colombian Applied Linguistics Journal, 17(1), 53-63. https://doi.org/10.14483/udistrital.jour.calj.2015.1.a04

Savin-Baden, M., \& Wimpenny, K. (2007). Exploring and implementing participatory action research. Journal of Geography in Higher Education, 31(2), 331-343.

Setyaningsih, E. (2019). Bringing critical literacy into tertiary EFL reading class. Indonesian Journal of Applied Linguistics, 9(2), 297-307. https://doi.org/https://doi.org/10.17509/ijal.v9i2.20220

Slee, P. (2017). School bullying: Teachers helping students cope. Taylor \& Francis.

Stasz, B. B., \& Bennett, B. (1997). Little Red rides the hood: Teaching preservice teachers how to use children's literature by writing it. Journal of Adolescent \& Adult Literacy, 40(8), 622-628.

Suarcaya, P., \& Prasasti, W. D. (2017). Investigating students' critical reading: Critical literacy in EFL setting. Electronic Journal of Foreign Language Teaching, 14(2), 220-232.

Sun, L. (2019). Words and actions: An EFL teacher's critical literacy goals \& their enactment in a reading class in China. Multicultural Education, 26(3/4), 10-16.

Tatar, M. (Ed.). (1999). The classic fairy tales: A Norton Critical Edition. W.W. Norton \& Company.

Torres, M. N. (2017). Prospective teachers learning to engage reluctant writers: The power of experiential critical literacy pedagogies. Journal of Teacher Action Research, 4(1), 101-116.

Tsai, S.-J. V. (2010). Exploring the possibilities in Taiwan for critical literacy through multiple learning sources [Master's Thesis, Tunghai University]. Tunghai University Institutional Repository. http://thuir.thu.edu.tw/retrieve/13259/099THU00094002-001.pdf

Utami, T. (2018). Bullying in The Ugly Duckling illustrated story [Undergraduate Thesis, Universitas Pamulang]. Universitas Pamulang Digital Repository. http://eprints.unpam.ac.id/6707/.

Wagner, T. (2012). The making of criminal children: Stealing orphans from Oliver Twist to A Little Princess. Victorians: A Journal of Culture and Literature (121), 68+.

https://link.gale.com/apps/doc/A288536750/LitRC?u=utas1\&sid=googleScholar\&xid=b63c5d0e 
Wee, S.-J., Kim, K. J., \& Lee, Y. (2017). 'Cinderella did not speak up': Critical literacy approach using folk/fairy tales and their parodies in an early childhood classroom. Early Child Development and Care, 189(11), 18741888. https://doi.org/10.1080/03004430.2017.1417856

Wu, C.-H. (2014). Reflections on teaching critical literacy: Reading through Sherlock Holmes mysteries. TESOL International Journal, 9(1), 92-104.

Zipes, D. J. (1988). The Brothers Grimm: From enchanted forests to the modern world. Routledge.

Zipes, J. D. (1979/1992). Breaking the magic spell: Radical theories of folk and fairy tales. Routledge.

Zipes, J. D. (1983). Fairy tales and the art of subversion: The classical genre for children and the process of civilization. Routledge.

Zipes, J. D. (2013). Why fairy tales stick: The evolution and relevance of a genre. Routledge. https://doi.org/10.4324/9780203700662

Zipes, J. D. (Ed.). (2015). The Oxford Companion to Fairy Tales (2nd ed.). Oxford Press University.

How to cite this paper:

Novianti, N. (2021). Introducing Critical Literacy to Pre-Service English Teachers through Fairy Tales. Journal of Literary Education, (4), 196-215. https://doi.org/10.7203/JLE.4.21026 